\title{
Digital Class Model in Mathematics Learning in Elementary School Using Social Learning Network Schoology
}

\author{
Y Helsa $^{1}$, Y Ariani ${ }^{2}$, A K Kenedi $^{3}$ \\ Universitas Negeri Padang, Jl. Prof Dr. Hamka Air Tawar, Padang, Indonesia ${ }^{1,2}$ \\ Universitas Samudra, Jl. Meurandeh, Langsa, Indonesia ${ }^{3}$ \\ \{yullys@fip.unp.ac.id\}
}

\begin{abstract}
The development of Industry 4.0 requires an increase in teacher innovation in conducting mathematics learning process in elementary school. Development of Industry 4.0 is not accompanied by an increase in teachers ability to innovate learning. The purpose of this training is to improve teachers ability to develop a digital class model in mathematics learning in elementary schools by utilizing social learning network schoology. This training method is to provide guided training to elementary school teachers. The results stated that teachers motivation and skills in developing digital classroom models in mathematics learning by utilizing social learning network schoology increases. The implication of this training is as teachers' reference in developing a digital class model in their respective schools.
\end{abstract}

Keywords: Digital Class Model, Mathematics Learning, Social Learning network schoology, Elementary School

\section{Introduction}

The stage of the intellectual development of elementary school students is included in a concrete operational stage because the logic of thinking is still based on physical manipulation of object [1]. The use of media (including teaching aids) in learning mathematics is very necessary because it is following the stage of children thinking. The use of media in learning mathematics will bring results six times better and faster than teaching without concept [2]. Nowadays, learning activity in elementary schools cannot avoid the rapid development of technology [3]. This is because the development of industry 4.0 has influenced a learning system [4] [5] [6]. Industry 4.0 demands a change in learning by using technology-based learning system [7] [8] [9]. A technology-based learning system creates a learning process that requires the collaboration of teachers and students with technological skills. This is what triggers many researchers to create a learning process to answer the challenges of industry 4.0. One of the most popular lessons at the moment is online learning.

Online learning is learning that facilitates teachers and students to interact using the network [10] [11]. Many studies suggest that online learning can improve the quality of learning such as increasing learning independence, improving communication skills, learning can be carried out anytime and anywhere, increasing learning resources, and increasing 
student activity [12] [13] [14] [15]. These benefits will lead to student learning outcomes. Thus, the research makes foundation educators develop learning processes conducted online. This has resulted in many online learning systems by providing facilities for teachers to arrange, design, implement learning, even for assessment and discussion. Learning management system (LMS) provides interesting activities to make the learning process more friendly for students hence they can increase students' interest in learning mathematics and enable students to share their knowledge and difficulties, consequently they can help each other [16].

One of the learning media with information technology is known as online learning or more commonly known as e-learning. E-learning platforms include Edmodo, Moodle, Schoology, Quipper School, Dokeos, and dotLRN. One of the popular e-learning methods in Industry 4.0 is Schoology. Schoology is an online learning media facilitates for learning, consists of attendee list for student attendance, courses for classifying subject, resources for adding material, assignments, quizzes, discussion rooms, etc. Schoology makes it easy for educators to present online learning [17] [18]. One of the main advantages provided by online learning for students is flexibility. They can access learning virtually anywhere with internet access. Each student can adjust when and how long they want to participate, depending on their daily commitment. Besides, students will save time and transportation costs needed when going to a learning location [19]. Through the features provided, schoology can design elementary mathematics learning that is meaningful to students. It also draws students closer to technology and information in teaching and learning activities.

This training is based on the service program of Padang State University as stipulated in Padang State University strategic plan (2016-2020), namely increasing the relevance, quantity, and quality of resources by realizing quality services under customer needs [20]. Padang State University is one of the Institute of Teacher's Education that produces professional teachers in Technology and Information field under current advancements. Based on observation and interview with mathematics teachers, it was concluded that schools still do not have digital classes, but there are further plans for the government to establish digital classes for elementary schools. However, many teachers still do not understand the concept of this digital class. Based on the analysis, it can be concluded that there is a future effort in developing digital classes but the teacher still does not have sufficient knowledge and skills. Therefore, an effort is needed to train teachers to understand the concept of digital classes for elementary schools. Subsequently, this training aims to improve teachers ability to develop digital classroom model in mathematics learning in elementary schools by utilizing social learning network schoology

\section{Method}

The training provided consisted of two stages. The first stage, the teacher is tutored in knowledge about digital classroom development using schoology and in the second stage, the teacher is prepared to develop the digital classroom. The research subjects were an elementary school in cluster I, North Payakumbuh Subdistrict, Indonesia, as many as 50 people. To see the process, researchers conducted evaluations in pre-training and during training. The evaluation of this training focused on teachers motivation and skills in developing digital classes. Data collection instruments are using a questionnaire, test, observation, and documentation. 
Indicator of successful training is teachers skills before training compared to after training increases [21].

\section{Results and Discussion}

Learning using the Schoology platform can be done anywhere, anytime and through any device. This provides significant benefits for students, teachers, schools, and parents. The implementation of digital classroom development by utilizing social learning network schoology was carried out on Wednesday and Thursday 19 and 20 June 2019. Student Creativity Program originally targeted 30 teachers but it suddenly increased to 50 teachers. This is following the discussion with the cluster I, North Payakumbuh district. The reason for an equal distribution of opportunities and the amount of participants interest were taken into consideration by increasing the number of training participants. This training was carried out in collaboration with Cluster I of North Payakumbuh sub-district and at Islamic Elementary School in Payakumbuh City. The training was filled by three speakers from Universitas Negeri Padang. The results of the training can be seen in the table below.

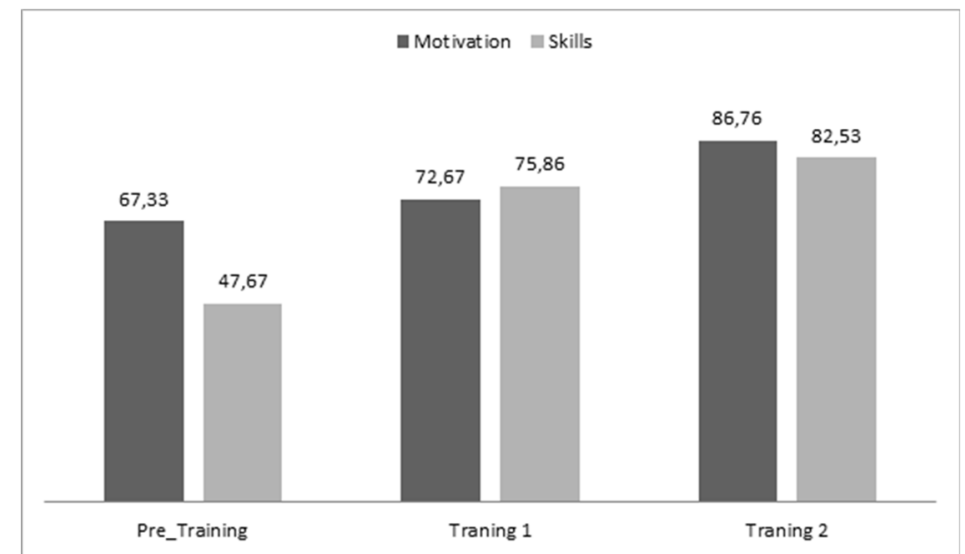

Fig. 1. The graph of teacher training results

Based on the picture above, there is an increase in teachers motivation and skills from pretraining, training 1 and training 2 . This proves that the training provided is successful under the indicators determined. Some things should be discussed in the training. The first relates to teacher motivation. At first, teachers motivation seem lacking in the development of digital classes by utilizing social learning network schoology. School use guide consists of three parts, namely the use of schoology for teachers, students and parents. The teacher's enthusiasm is increasingly visible when connected with the future educational process by utilizing technology in the learning process. Teacher motivation is one of the success factors in achieving learning goals [22] [23] [24]. Motivation is encouragement from within to do something. Teachers with high motivation towards learning process will be easy to create innovation to improve the quality of learning.

Secondly, the enthusiasm of the teacher takes part in the training. After giving motivation by the first speaker, teachers seem enthusiastic in listening and discussing when the second speaker demonstrated the implementation of digital classroom learning by utilizing schoology. 
After the interview, this enthusiasm is caused by various reasons, such as the desire to improve teachers ability to design digital classes using the schoology platform and carry out learning with digital classes using the schoology platform. The teacher has a high responsibility in the learning process [25]. Teachers must create a learning atmosphere to facilitate students in achieving learning objectives [26] [27]. With the activeness of the teacher in the training, the process shows that the teacher is trying to achieve the goals.

The third is a constraint experienced by the teacher during training using the schoology platform. Teachers seem to have difficulty understanding every feature on the schoology homepage. However, after the assistance was carried out by involving the speakers and implementing committee, this difficulty could be overcome. The teachers look so eager to share the problems they have and the solutions offered to overcome the problems they face. The teachers then tried to design digital classes with the help of the speakers and the organizing committee. This can improve teacher skills in developing digital classes using schoology. The training provided is guided training. Guided training has many advantages that can transfer knowledge and skills directly [28] [29]. Therefore if obstacles found, they can be guided directly in the training process.

From the explanation above it can be concluded that teachers motivation and skills in developing digital classes in learning mathematics increases by using schoology. Schoology is a type of social learning management system (LMS) offering free and easy to use learning [30]. Schoology is one of the web-based social page offering the same free and easy to use learning such as Facebook [31]. Schoology was chosen in this study because schoology can combine social networking features with a learning management system accordingly it can socially interact while learning [32]. Thus it provides opportunities for wider interaction between teachers, students, and learning resources. Besides, the advantages of schoology, among others: a) Schoology provides more choices of resources than Edmodo. b) Schoology can accommodate the type of questions (question bank) used during the quiz. c) Schoology provides attendance facilities used to check student attendance. d) Schoology also provides analytical facilities to see all student activities on each course, assignments, discussions and other activities prepared for students [33]. Finally, schoology provides many features to create online learning processes that easily understood by users.

The aim of developing and integrating Schoology in elementary schools is to connect teachers, students and parents in virtual classrooms, technology-supported, to improve student learning outcomes [34]. The involvement of teachers, students, and parents is needed in the era of Industry 4.0 because the learning process can occur from anywhere and at any time. Therefore the training given to teachers can be implemented in the process of learning mathematics in schools.

\section{Conclusion}

It concludes that after the implementation of digital classroom development training by utilizing the social learning network Schoology, teachers motivation and skills in developing digital classes improves:

\section{Acknowledgment}

Thank you to Univesitas Negeri Padang for facilitating this research. 


\section{References}

[1] A Kiswanto 2017 Adv. Soc. Sci. Educ. Humanit. Res. 1181040

[2] N Andrijati 2014 J. Penelit. Keislam 31123

[3] T Trust, D G Krutka and J Paul 2016 Comput. Educ. 10215

[4] A A Hussin 2018 International Journal of Education and Literacy Studies 692

[5] A Shahroom and N Hussin 2018 International Journal of Academic Research in Business and Social Sciences 8314

[6] K Umachandran, I Jurcic, J Ferdinand, M M T Said and A A Rashid 2018 International Journal Of Computers \& Technology 177305

[7] L Angelianawati 2019 Jurnal Dinamika Pendidikan 11307

[8] V Dwiyanti, A Ana and I Widianingsih 2018 Innovation of Vocational Technology Education 1498

[9] A Hariharasudan and S Kot 2018 Social Sciences 7227

[10] H R Robles, J Guerrero, H Llinas and P Montero 2019 Journal of Information Technology Education: Research 18231

[11] N I Scagnoli, L P Buki and S D Johnson 2009 Journal of Asynchronous Learning Networks 13115

[12] O O Jethro, A M Grace and A K Thomas 2012 International Journal of Academic Research in Business and Social Sciences 2207

[13] E Kahiigi Kigozi, L Ekenberg, H Hansson, M Danielson and F F Tusubira 2008 IADIS International Conference e-Learning vol 2008 (Amsterdam/DIVA) p. 195.

[14] D R Garrison and M Cleveland-Innes 2005 The American journal of distance education 19140.

[15] T Kattoua, M Al-Lozi and A A Alrowwad 2016 International Journal of Business Management \& Economic Research 7760

[16] N Cavus and M S Alhih 2014 Procedia - Soc. Behav. Sci. 143519

[17] A S Sicat 2015 International Journal of Education and Research 3161

[18] S Biswas 2013 Northwest Journal of Teacher Education 11190

[19] Tinschert 2006 Implementation of a Learning Management System for a small American company (Wildau: University of Applied Sciences Wildau)

[20] UNP 2016 Renstra UNP 2016-2020 (Padang: UNP)

[21] V M Rudhaliawan 2013 Jurnal Administrasi Bisnis 41

[22] N Börü 2018 International Journal of Instruction 11770

[23] E Vero 2014 semantic scholar 360

[24] J Han and H Yin 2016 Cogent Education 31217819.

[25] M Shabir 2015 AULADUNA: Jurnal Pendidikan Dasar Islam 221

[26] M M Mugambi, D K Mwove and F G Musalia 2015 Journal of Educational Policy and Entrepreneurial Research 2100

[27] J R Putra 2017 Retrieved on March 23rd. 218230

[28] E K Nisa et al 2018 J. Phys.: Conf. Ser. 997012049

[29] I P Artayasa, H Susilo, U Lestari dan E Indriwati 2017 Journal of Baltic Science Education 166

[30] J B Huang, J Lang and C J Xiao Proceedings of the 2nd International Conference on Computer Science and Electronics Engineering vol 2013(Paris/Atlantis Press)

[31] B Rosy 2018 Indonesian J. Informatics Educ. 21

[32] R Purwaningsih, U.Rosidin and I Wahyuni 2017 Jurnal Pembelajaran Fisika 560

[33] A Efendi 2017 Electronics, Informatics, Vocat. Educ. 249 
[34] A K Jayadinata 2013 Prosiding Seminar Nasional Pendidikan Dasar. Universitas Pendidikan Indonesia Kampus Sumedang vol 1 (Bandung/ UPI) p. 17 